\title{
OPTIMALISASI PENGGUNAAN LEARNING MANAGEMENT SYSTEM(LMS) DALAM PEMBELAJARAN VIRTUAL UNTUK GURU DI LINGKUNGAN LEMBAGA PENDIDIKAN MA'ARIF NU JEMBER
}

\author{
Moh. Arif Mahbub \\ Universitas Islam Jember, Jember, Indonesia \\ rifelbarzmahbub@gmail.com
}

\begin{abstract}
Abstrak: Pemberlakuan pembelajaran jarak jauh (PJJ) daring (dalam jaringan) akibat krisis pandemi global Covid-19 di Indonesia memberikan tantangan tersendiri khususnya bagi para pendidik. Kesiapan kompetensi guru dalam mengelola kelas daring dan kemampuan beradaptasi dengan moda pembelajaran virtual menjadi faktor kunci keberhasilan PJJ daring tersebut. Namun, data empiris menunjukkan ketidaksiapan para guru dalam mengimplementasikan PJJ daring ini. Program pengabdian kepada masyarakat ini bertujuan untuk mengoptimalkan penggunaan Edmodo dalam PJJ daring. Kegiatan ini diikuti oleh 32 peserta yang merupakan para guru yang mengajar dilingkungan LP Ma'arif NU cabang Jember. Prosedur pelaksanaan program pengabdian ini terdiri dari tiga tahap yaitu eksplorasi, elaborasi, dan konfirmasi. Hasil pengabdian menunjukkan adanya respon yang sangat positif dari para peserta pelatihan terkait integrasi Edmodo dalam PJJ daring. Selanjutnya, simpulan, keterbatasan, dan rekomendasi hasil program pengabdian didiskusikan dalam artikel ini.
\end{abstract}

Kata Kunci: Edmodo, learning management system (LMS), pembelajaran jarak jauh, pembelajaran virtual

\begin{abstract}
Online learning during Covid-19 outbreak in Indonesia has seriously challenged the teachers. The teachers' competencies in managing their online courses and the level of adaptability to virtual learning environments are both crucial factors to a successful online learning. However, empirical data demonstrate the low levels of readiness regarding the implementation of this online learning. As an attempt to resolve this problem, this community service program aims to optimize the use of Edmodo in online learning. Thirty-two teachers from Ma'arif Nahdlatul Ulama Educational Institution (LP Ma'arif NU) in Jember voluntarily participated in this program. The program was held in three phases; exploration, elaboration, and confirmation. It is found that the participants mostly have positive feelings about the integration of Edmodo into online learning. Furthermore, the conclusions, limitations, and recommendations of the program results are discussed in this article.
\end{abstract}

Keywords: Edmodo, learning management system (LMS), virtual learning, distance learning

\section{Pendahuluan}

Sejak dideklarasikannya Covid-19 (SARS-Cov-2) sebagai pandemik global oleh organisasi kesehatan dunia (WHO) (Sohrabi et al., 2020), banyak Negara didunia telah menerapkan kebijakan untuk melakukan physical/social distancing untuk memutus rantai penyebaran virus tersebut. Data empiris yang didapatkan dari beberapa penelitian terkini melaporkan bahwa lebih dari 95\% Negara di berbagai belahan dunia melaporkan adanya kasus penularan virus tersebut (Schlenz et al., 2020; Sohrabi et al., 2020). Krisis kesehatan dunia yang disebabkan oleh virus tersebut sangat berdampak pada seluruh sendi kehidupan. Di Indonesia, salah satu sektor yang sangat terdampak adalah sektor pendidikan dimana pemerintah Indonesia memberikan respon dengan memberlakukan pembelajaran jarak jauh (distance learning) mulai dari tingkat pendidikan dasar sampai pada perguruan tinggi, yang 
dimulai pada bulan Maret 2020 (Atmojo \& Nugroho, 2020). Pemberlakuan regulasi ini mengakibatkan adanya migrasi moda pembelajaran dari pembelajaran tatap muka (face-toface learning) menjadi moda pembelajaran daring secara penuh.

Pada dasarnya, e-learning didefinisikan sebagai pembelajaran yang mengintegrasikan perangkat teknologi informasi dan komunikasi (Amichai-hamburger, 2009; Amir et al., 2020; Atmojo \& Nugroho, 2020; Basak, Wotto, \& Bélanger, 2018). Selama dua dekade terakhir, integrasi pembelajaran berbasis internet ini semakin menjamur, terutama ditingkat pendidikan tinggi (Martin et al., 2020; Pei \& Wu, 2019). Beberapa literatur ilmiah dari penelitian terdahulu melaporkan bahwa e-learning sangat efektif diterapkan dalam kegiatan belajar-mengajar diberbagai disiplin ilmu (Amir et al., 2020; Lamb \& Arisandy, 2020; Schlenz et al., 2020; Tsai et al., 2017).

Seiring dengan berkembangnya teknologi yang semakin pesat, pemanfaatan teknologi berbasis internet dalam domain pendidikan sudah mengarah pada prioritas penggunaan software yang mampu mengorganisir proses belajar-mengajar secara efektif dan efisien dimana para siswa/siswi tidak perlu datang secara fisik ke sekolah. Pemanfaatan teknologi berbasis internet dalam pembelajaran daring ini juga mampu untuk memberikan akses seluasluasnya terhadap ketersediaan materi belajar tanpa terbatas ruang dan waktu (anytimeanywhere learning), dan mereduksi tingginya biaya untuk mencetak materi (Nurakun Kyzy, Ismailova, \& Dündar, 2018).

Learning Management System (LMS) merupakan perangkat utama dalam pembelajaran e-learning (Kerimbayev et al., 2017). Platform daring ini mampu menyimpan seluruh materi dan aktifitas pembelajaran (Hamidi et al., 2020) sehingga memudahkan para instruktur dan siswa untuk saling terhubung dan berinteraksi satu sama lain dalam hal berbagi materi dan aktifitas-aktifitas pembelajaran lainnya didalam kelas (Adzharuddin \& Ling, 2013).

Salah satu perangkat LMS yang digunakan dalam kegiatan abdimas ini adalah Edmodo. Edmodo merupakan salah satu platform social networking sites(SNS) seperti halnya Facebook dan Twitter yang memberikan fasilitas kepada guru, siswa, dan, bahkan, orang tua untuk saling berkolaborasi, berkomunikasi, berbagi materi, dan juga untuk melakukan penilaian (assessment) (Balasubramanian et al., 2014). Adapun pemilihan Edmodo dalam kegiatan abdimas ini adalah berdasarkan beberapa pertimbangan yang dikutip dari beberapa riset sebelumnya (Ateş Çobanoğlu, 2018; Balasubramanian et al., 2014; Durak, 2017; Hamidi et al., 2020; Monalisa \& Ardi, 2013; Unal \& Uzun, 2020), antara lain 1) platform ini tak berbayar, 2) tampilannya menyerupai Facebook sehingga lebih familiar, 3) adanya fitur multi-bahasa, 4) memberikan akses konektifitas digital antar guru-siswa kapan saja dan dimana saja, 5) para orang tua juga dapat mengecek pekerjaan dari anak-anaknya dan memantau kemajuan belajar mereka, 6) efisiensi kegiatan evaluasi melalui fitur quiz, tugas, dan polling, dan 7) adanya fasilitas gradebook untuk melakukan manajemen nilai baik secara manual maupun otomatis.

Seperti yang sudah dipaparkan sebelumnya, pemberlakuan pembelajaran jarak jauh (PJJ) dimasa pandemik ini memang sudah menjadi suatu keharusan. Namun, pada praktiknya, penerapan pembelajaran ini juga mengalami banyak kendala. Selain dari aspek psikologis 
seperti isu kedisiplinan, motivasi, kesehatan mental dan fisik, dan perasaan saat isolasi (Raaper \& Brown, 2020), kesiapan kompetensi guru dalam mengelola kelas virtual juga menjadi salah satu kendala tersendiri. Temuan-temuan empiris dari beberapa penelitian sebelumnya juga menyebutkan bahwa technophobia dan kurangnya kompetensi para guru menjadi masalah serius dalam pemberlakuan pembelajaran daring (Blake, 2007; Celik, 2013). Hal senada juga dialami oleh para guru dilingkungan LP Ma'arif NU cabang Jember. Technophobia dan kurangnya pemahaman terhadap pentingnya integrasi teknologi dalam pembelajaran menjadikan mereka skeptis terhadap teknologi itu sendiri.

Berdasarkan hasil wawancara virtual dengan beberapa Kepala Sekolah dilingkungan LP Ma'arif NU cabang Jember, diperoleh data bahwasannya pada awal masa pandemi (sekitar awal April-Juni 2020) sebagian besar sekolah memang belum memberlakukan pembelajaran jarak jauh (PJJ) daring secara penuh. Banyak institusi yang masih melaksanakan pembelajaran hanya sebatas pada pemberian tugas mingguan saja. Siswa-siswi diperintahkan untuk mengambil tugas ke sekolah dan diminta untuk mengumpulkannya kembali pada waktu yang sudah ditentukan dan disepakati. Untuk penilaian tengah semester (PTS) dan penilaian akhir semester (PAS) juga masih memberlakukan regulasi seperti yang telah disebutkan sebelumnya. Data empiris dari hasil wawancara tersebut juga mengungkapkan ada beberapa faktor yang menyebabkan kondisi tersebut, antara lain 1) kurangnya pengalaman guru dalam mengelola pembelajaran daring, 2) belum pernah menyelenggarakan pembelajaran campuran (blended learning) sebelum masa pandemi, dan 3) investasi infrastruktur Teknologi Informasi yang kurang memadai. Faktor-faktor tersebut juga serupa dengan yang telah ditemukan oleh beberapa penelitian sebelumnya (Alsswey \& Al-Samarraie, 2019; Celik, 2013; Ferdiansyah Supiastutik, \& Angin, 2020; French, Guo, \& Shim, 2014). Selain itu, terbatasnya akses untuk menggunakan handphone, khususnya bagi para siswa yang belajar di bawah naungan pondok pesantren, juga merupakan kendala utama belum terlaksananya pembelajaran daring ini.

Seiring berjalannya waktu, pada awal tahun akademik baru 2020-2021 proses belajarmengajar di beberapa institusi sudah mulai melaksanakan pembelajaran daring. Hal ini terbukti dengan adanya proses pembelajaran daring dengan konferensi virtual dengan memanfaatkan media Zoom dan Google Meet. Banyak guru yang juga memanfaatkan grup chat WhatsApp kelas untuk berdiskusi materi dan mengunggah tugas-tugas pembelajaran. Untuk assessment, mereka memanfaatkan fasilitas quiz pada Google Form namun rekapitulasi hasil belajar masih belum terekam dengan baik, khususnya untuk mata pelajaran yang menekankan pada praktikum. Dalam hal ini, Osman (2020) merekomendasikan untuk menyediakan berbagai macam tipe metode alternative assessment dan rubrik penilaian yang relevan sehingga proses penilaiannya lebih efektif dan hasil penilaiannya menjadi lebih valid dan reliabel. Seperti yang telah dipaparkan sebelumnya, diketahui bahwa pada dasarnya PJJ daring ini sudah dilaksanakan namun perencanaan desain pembelajarannya masih belum dirumuskan dengan baik. Perencanaan, perancangan, dan perumusan tujuan pembelajaran yang cermat memang menjadi sebuah keharusan dalam PJJ daring, seperti yang direkomendasikan oleh Osman (2020).

Data wawancara juga menunjukkan kurangnya usaha dan dukungan institusi dalam 
memfasilitasi para guru untuk meningkatkan profesionalitas mereka dengan memberi kesempatan bagi para guru untuk ikut serta dalam pelatihan-pelatihan pengembangan bahan ajar yang sesuai dengan kondisi saat ini. Untuk merespon hal tersebut, banyak guru yang belajar secara mandiri dan dengan mengikuti workshop atau pelatihan-pelatihan pengembangan bahan ajar dalam PJJ daring yang diselenggarakan oleh berbagai perguruan tinggi dan Musyawarah Guru Mata Pelajaran (MGMP) didaerah mereka. Data diatas menunjukkan adanya ketidaksiapan dari institusi untuk merespon pembelajaran "tiba-tiba daring" dalam situasi krisis global ini. Menurut Hastowahadi, Setyaningrum, \& Pangesti, (2020) kesiapan dan kemampuan beradaptasi dalam situasi sekarang ini menjadi faktor kunci keberhasilan PJJ daring.

Oleh karena itu, kegiatan pengabdian kepada masyarakat ini diselenggarakan untuk menjembatani kesenjangan-kesenjangan tersebut. Kegiatan abdimas ini merupakan kegiatan pelatihan optimalisasi penggunaan Edmodo sebagai salah satu LMS dalam pembelajaran daring. Kegiatan ini bertujuan untuk memberikan wawasan akan pentingnya technointegration dalam pembelajaran dan juga untuk mengeksplorasi pengalaman dan tanggapan para guru terkait optimalisasi penggunaan Edmodo untuk mengelola kelas daring mereka selama kegiatan abdimas ini.

\section{Metode}

Kegiatan abdimas ini diikuti oleh 32 (31,25\% perempuan, dan 68,75\% laki-laki) peserta yang merupakan para guru dilingkungan LP Ma'arif NU cabang Jember. Mereka adalah para guru dari berbagai disiplin ilmu yang berasal dari berbagai institusi pendidikan di Lingkungan LP Ma'arif NU di Kabupaten Jember, mulai dari tingkat dasar hingga tingkat menengah. Mayoritas peserta sudah memiliki kualifikasi akademik strata 1 (S1) dan ada beberapa guru yang sedang melanjutkan studi pada program pascasarjana (S2).

Adapun prosedur pelaksanaan kegiatan abdimas ini meliputi beberapa tahap, yang mengadopsi dari Tarmini et al. (2020), yakni: eksplorasi, elaborasi, dan konfirmasi. Pada tahap eksplorasi, penulis melakukan wawancara daring dengan beberapa kepala sekolah dilingkungan LP Ma'arif NU cabang Jember. Hal ini dilakukan untuk mengetahui kondisi awal dan permasalahan mitra terkait penggunaan LMS dalam pembelajaran daring selama masa pandemik. Tahap elaborasi dilaksanakan pada saat pelatihan. Adapun kegiatannya meliputi 1) urgensi pelaksanaan PJJ dan penjelasan tentang LMS secara umum, 2) penjelasan aplikasi Edmodo dan penggunaannya, 3) demonstrasi penggunaan Edmodo, dan 4) mendesain pengelolaan kelas virtua/dengan menggunakan Edmodo sebagai produk akhir.

Selanjutnya, tahap akhir dari pelaksanaan kegiatan abdimas ini adalah melakukan pengumpulan data terkait bagaimana tanggapan dan pendapat para peserta pelatihan terhadap penggunaan Edmodo dalam konteks ini. Proses pengumpulan data ini bertujuan untuk mengeksplorasi tanggapan mereka terhadap integrasi Edmodo dalam pembelajaran daring yang dilaksanakan dengan melakukan wawancara semi-struktur dengan beberapa peserta yang meliputi beberapa bagian, yaitu: 1) kemampuan peserta untuk mengoperasikan 
Edmodo, 2) peran Edmodo dalam memfasilitasi pembelajaran kapan saja-dimana saja, 3) peran Edmodo dalam memediasi interaksi guru-siswa, dan 4) peran Edmodo dalam proses evaluasi PJJ daring. Wawancara ini direkam secara audio (audio-recorded) dan ditranskripsi yang dilengkapi dengan penambahan informasi yang mendukung, sesuai yang direkomendasikan oleh Widodo (2014). Adapun proses analisa datanya juga mengadopsi dan mengadaptasi prosedur analisa data yang dikemukakan oleh Widodo (2014) yang meliputi 1) mendengarkan hasil wawancara secara berulang-ulang, 2) menuliskan data, 3) mengkodifikasi dan menginterpretasi data, dan 4) membangun kredibilitas data dengan melakukan memberchecking dengan cara memberikan kesempatan kepada para partisipan untuk memberikan umpan balik (feedback), baik untuk mengkonfirmasi dan menyangkal hasil interpretasi data, untuk lebih meningkatkan tingkat akurasi data.

\section{Hasil dan Pembahasan}

Pada saat proses pelaksanaan pelatihan, sesi eksplorasi dilakukan dengan cara wawancara singkat dengan para peserta yang berisi sejumlah pertanyaan terkait dengan 1) bagaimana kondisi PJJ daring di sekolah masing-masing, 2) media apa sajakah yang sudah diintegrasikan dalam PJJ daring, 3) Penggunaan LMS di kelas masing-masing, dan 4) metode evaluasi selama PJJ daring. Hasilnya dapat mengindikasikan bahwa pada umumnya PJJ daring masih belum terlaksana secara optimal dengan berbagai kendala yang dihadapi baik dari pihak lembaga, guru, dan siswa. Terkait dengan penggunaan media, mayoritas menjawab masih memanfaatkan beberapa media sosial untuk berinteraksi, berdiskusi dan berbagi materi pembelajaran, dan mengunggah berbagai tugas pembelajaran. Selanjutnya, data wawancara juga mengungkapkan banyak peserta yang belum mengenal LMS dan fungsinya. Namun demikian, data juga menunjukkan ada beberapa peserta yang mengaku sudah menerapkan Edmodo dikelasnya. Selaras dengan hasil wawancara dengan Kepala Sekolah, banyak dari peserta yang memanfaatkan Google Form untuk melaksanakan evaluasi pembelajaran baik untuk formative dan summative assessment.

Selanjutnya, tahap elaborasi dilakukan dalam beberapa tahap. Tahap pertama dilakukan dengan cara penyampaian materi terkait urgensi pelaksanaan PJJ dan penjelasan tentang LMS secara umum. Hal ini bertujuan untuk memberikan wawasan atau dasar pemikiran kepada para peserta tentang kondisi riil saat ini yang mengharuskan perubahan moda belajar dari pembelajaran tatap muka (face-to-face learning) menjadi PJJ daring. Setelah itu, para peserta dikenalkan dengan beberapa LMS termasuk Edmodo sebagai salah satu platform media sosial gratis untuk memudahkan para guru dalam pengelolaan kelas daring mereka secara efektif dan efisien. Penyampaian materi Edmodo ini meliputi penjelasan fitur, fungsi, kelebihan, dan pemodelan bagaimana mengoperasikannya. Pada tahap demonstrasi, instruktur memberikan kesempatan bagi para peserta untuk berdiskusi terkait bagaimana mendesain dan mengelola kelas virtual dengan menggunakan Edmodo. Pada tahap ini, peserta juga mulai mendesain kelas daring mereka secara mandiri mulai dari proses enrolment, berbagi sumber belajar, mendistribusikan tugas, pemberian umpan balik (feedback), dan pelaksanaan kegiatan 
evaluasi. Sayangnya, tahap pemodelan dan demonstrasi ini memakan waktu yang agak lama (sekitar 2 jam) yang mengakibatkan tidak terlaksananya presentasi dari beberapa peserta.
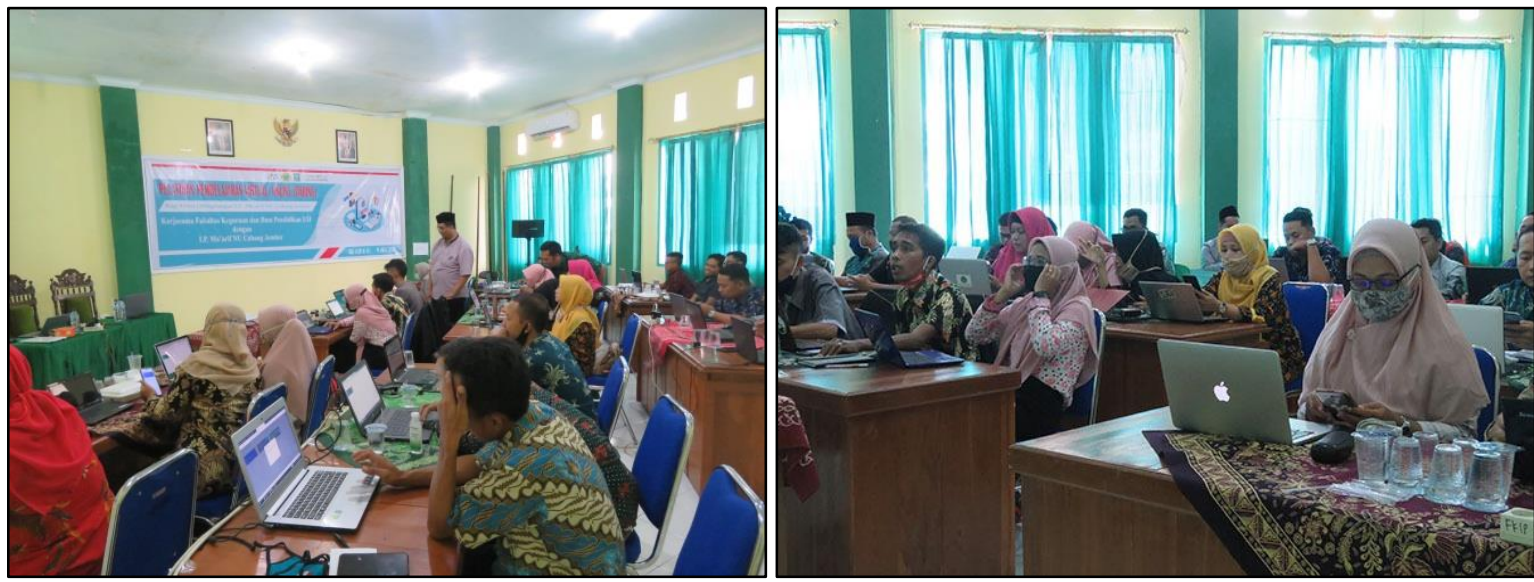

Gambar 1. Penyampaian materi integrasi LMS (Edmodo) dan demonstrasi penggunaannya

Tahap konfirmasi meliputi proses pengumpulan data untuk mengeksplorasi pendapat para peserta pelatihan terkait integrasi Edmodo dalam PJJ daring melalui wawancara semistruktur kepada beberapa peserta pelatihan. Berdasarkan hasil wawancara, diperoleh data bahwa pada dasarnya untuk mengopersikan Edmodo tidaklah sulit. Hal ini diungkapkan dalam data wawancara berikut:

\section{Menurut pendapat saya, [terkait pengoperasian Edmodo] mungkin sebenarnya mudah. Tapi, karena saya sendiri belum pernah menggunakan aplikasi tersebut untuk fasilitas belajar dan pemberian tugas, maka pengoperasiannya menjadi sulit dan perlu belajar lagi. (AS \#2, Wawancara, 11 Juli 2020).}

Edmodo memiliki cara pengoperasian yg mudah baik dari guru maupun siswa. Hanya membutuhkan pemahaman tentang fitur-fitur yg tersedia dalam aplikasi Edmodo. (MS \#3, Wawancara, 11 Juli 2020).

Kutipan hasil wawancara diatas mengindikasikan bahwa pada dasarnya mereka menyukai aplikasi platform daring ini. Perasaan suka terhadap sistem pembelajaran melalui Edmodo ini akan menimbulkan anggapan bahwa untuk mengoperasikannya sangat mudah, selaras dengan yang dikemukakan oleh Unal \& Uzun (2020). Meskipun demikian, mereka merasa bahwa untuk memanfaatkan semua fitur yang ada pada Edmodo secara maksimal, mereka membutuhkan waktu yang cukup untuk mendalaminya. Pelatihan yang hanya satu hari ini dirasa sangat tidak cukup untuk memahaminya.

Selanjutnya, terkait dengan peran Edmodo dalam memfasilitasi pembelajaran kapan saja-dimana saja, beberapa peserta mengaku bahwa Edmodo dapat memfasilitasinya selama PJJ daring. Melalui berbagai fitur yang ada didalamnya, Edmodo memfasilitasi guru dan peserta didik untuk tetap bisa terhubung meskipun dalam masa pandemi. Berikut kutipan wawancara dengan mereka.

\section{Edmodo sangat memfasilitasi PJ] daring untuk masa pandemi ini. [Dengan}


Edmodo] Guru bisa [tetap] melaksanakan pembelajaran secara efektif. (MS \#3, Wawancara, 11 Juli 2020).

Edmodo [bisa] menjadi salah satu aplikasi yang dapat memfasilitasi guru dan peserta didik dalam melaksanakan PJj daring. Alasannya, dengan menggunakan Edmodo guru bisa membuat kelas sendiri untuk beberapa jenis mata pelajaran ... [dan] tidak perlu lagi membuat banyak grup WA tiap kelas. (FO \#1, Wawancara, 11 Juli 2020).

Meskipun demikian, salah satu peserta mengungkapkan keragu-raguannya dalam menerapkan Edmodo dalam PJJ daring ini. Hal ini disebabkan oleh kondisi dan situasi dalam institusinya yang berada dalam naungan Yayasan Pondok Pesantren yang menerapkan pembatasan akses bagi para santri, yang kebanyakan menjadi siswa-siswi disekolahnya, untuk menggunakan handphone selama didalam pesantren. Selain itu, faktor ekonomi juga harus dipertimbangkan. Hal ini dapat dilihat dari kutipan hasil wawancara berikut:

Iya, ... tapi mungkin gak ya diterapkan disekolah saya karena sebagian besar siswa saya berasal dari pondok pesantren dan dari kalangan orang tidak mampu yang tidak memungkinkan bagi mereka untuk memiliki gawai ataupun membeli paket data. (AS \#2, Wawancara, 11 Juli 2020).

Dalam hal mendeskripsikan peran Edmodo dalam memediasi interaksi guru-siswa, data mengungkapkan bahwa mereka sepakat untuk menyatakan bahwasannya Edmodo mampu memediasi interaksi antar guru dan siswa. Melalui fitur komentar dan tanggapan, guru dan siswa bisa dengan mudah untuk mendiskusikan materi pembelajaran, tugas-tugas, pemberian umpan balik, maupun interaksi pembelajaran lainnya. Hal ini serupa dengan yag dikemukakan oleh beberapa penelitian sebelumnya (Ateş Çobanoğlu, 2018; Siahaan, 2020; Unal \& Uzun, 2020) yang menyatakan bahwa Edmodo mendorong adanya interaksi positif antara guru dan siswa. Berikut adalah data narasi dari wawancara dengan beberapa peserta.

Edmodo mampu memfasilitasi interaksi antara guru dengan siswa ... dalam pembelajaran jarak jauh. (MS \#3, Wawancara, 11 Juli 2020).

Iya, pada aplikasi edmodo sudah tersedia kolom komentar dan tanggapan untuk setiap tugas yang diberikan oleh guru. ... juga tersedia menu join dengan banyak pihak jadi sangat mudah untuk berinteraksi atau sekedar sharing. (FO \#1, Wawancara, 11 Juli 2020).

Iya, tetapi membutuhkan lebih banyak waktu untuk menjawab pertanyaan siswa ketika terdapat kesulitan belajar ataupun memberikan feedback dari tugas-tugas siswa satu persatu. Sehingga kurang bisa mengakomodir komunikasi secara langsung. (AS \#2, Wawancara, 11 Juli 2020). 
Pertanyaan terakhir dari sesi ini mengeksplorasi tanggapan para peserta terkait penggunaan Edmodo dalam proses evaluasi pembelajaran. Beberapa dari mereka mengungkapkan perasaan positif mereka terhadap Edmodo dalam proses evaluasi. Fitur-fitur pembuatan kuis pada Edmodo dengan berbagai format soal, memudahkan para guru untuk membuat soal kuis dan ujian daring dengan lebih bervariasi. Penghitungan skor untuk beberapa tipe soal dapat dilakukan secara otomatis, namun khusus untuk tipe isian pendek dan uraian harus dikoreksi secara manual dikarenakan jawaban-jawabannya pasti sangat beragam. Untuk itu, guru harus meluangkan waktu yang cukup untuk melakukan koreksi pada tipe-tipe soal ini. Tanggapan dari peserta dinarasikan dalam kutipan berikut.

Iya, Edmodo membantu PJJ daring khususnya dalam [pelaksanaan] evaluasi. [Misalnya,] Siswa dapat mengerjakan tugas dalam bentuk file ataupun jpg dan guru bisa langsung mengoreksi dan mengevaluasi hasil belajar siswa. (FO \#1, Wawancara, 11 Juli 2020).

Iya sangat, karena banyak format kuis yang bisa digunakan. ... nilai siswa bisa langsung [secara otomatis] diketahui sehingga saya tidak perlu mengkoreksi secara manual. Tapi, untuk [format] kuis essay, [saya] butuh waktu untuk mengkoreksi dan menginput nilai secara manual karena nilai essay sangat variatif berdasarkan jawaban siswa [masing-masing]. (AS \#2, Wawancara, 11 Juli 2020).

\section{Kesimpulan}

Kegiatan abdimas ini bertujuan untuk memberikan wawasan akan pentingnya integrasi teknologi dalam PJJ daring dimasa krisis pandemi global ini dan mengeksplorasi pengalaman dan tanggapan para guru terkait optimalisasi penggunaan Edmodo untuk mengelola kelas daring mereka selama kegiatan abdimas ini. Hasil pelatihan ini mengindikasikan bahwa proses penerapan PJJ daring diberbagai institusi di lingkungan LP Ma'arif NU cabang Jember mengalami banyak kendala. Beberapa kendala yang dihadapi antara lain kurangnya kompetensi guru dalam mengelola PJJ daring, terbatasnya sarana infrastruktur TI, kemampuan adaptasi terhadap situasi belajar baru yang cenderung berjalan lamban, rendahnya motivasi belajar, disiplin diri, dan tingkat partisipasi siswa. Oleh karena itu, kegiatan pendampingan pembelajaran dalam hal integrasi teknologi, khususnya LMS, dalam PJJ daring ini memang sangat dibutuhkan dalam situasi pandemik seperti sekarang ini. Hal ini dibuktikan dengan antusiasme para peserta dalam mengikuti kegiatan ini. Keterampilan yang didapatkan dari kegiatan ini diharapkan mampu memberikan alternatif model pengelolaan kelas daring yang inovatif, interaktif, dan menyenangkan sehingga pada akhirnya akan menumbuhkan kemandirian belajar pada diri siswa.

Selanjutnya, penulis menyadari bahwa terdapat banyak kekurangan dalam pelaksanaan pelatihan ini. Pertama, kegiatan ini hanya diikuti oleh para guru dilingkungan LP Ma'arif NU cabang Jember dengan jumlah peserta yang relatif sedikit. Kegiatan selanjutnya diharapkan dapat menampung jumlah peserta yang lebih banyak dari berbagai level pendidikan, tidak 
hanya dilingkungan LP Ma'arif NU saja. Dikarenakan masih dalam situasi pandemi Covid-19, hendaknya kegiatannya dilakukan dengan moda daring melalui Zoom atau beberapa aplikasi lain sejenisnya. Kedua, kegiatan ini hanya memanfaatkan Edmodo. Kegiatan serupa dengan memanfatkan jenis-jenis LMS lain, seperti Google Classroom, Schoology, Moodle, dan lain sebagainya, hendaknya juga dilaksanakan. Disamping itu, durasi waktu yang terbatas sangat mempengaruhi terhadap tingkat daya serap materi dan praktik pelaksanaannya.

\section{Referensi}

Adzharuddin, N. A., \& Ling, L. H. (2013). Learning Management System (LMS) among University Students: Does It Work? International Journal of E-Education, E-Business, E-Management and E-Learning, 3(3), 248-252. https://doi.org/10.7763/ijeeee.2013.v3.233

Alsswey, A., \& Al-Samarraie, H. (2019). M-learning adoption in the Arab gulf countries: A systematic review of factors and challenges. Education and Information Technologies, 24(5), 3163-3176. https://doi.org/10.1007/s10639-019-09923-1

Amichai-hamburger, Y. (2009). E-learning: is technology the lighthouse? Policy Futures in Educcation, 76), 601-606. https://doi.org/http://dx.doi.org/10.2304/pfie.2009.7.6.601

Amir, L. R., Tanti, I., Maharani, D. A., Wimardhani, Y. S., Julia, V., Sulijaya, B., \& Puspitawati, R. (2020). Student perspective of classroom and distance learning during COVID-19 pandemic in the undergraduate dental study program Universitas Indonesia. BMC Medical Education, 20(1), 1-8. https://doi.org/10.1186/s12909-020-02312-0

Ateş Çobanoğlu, A. (2018). Student teachers' satisfaction for blended learning via Edmodo learning management system. Behaviour and Information Technology, 37(2), 133-144. https://doi.org/10.1080/0144929X.2017.1417481

Atmojo, A. E. P., \& Nugroho, A. (2020). EFL Classes Must Go Online! Teaching Activities and Challenges during COVID-19 Pandemic in Indonesia. Register Journal, 13(1), 49-76. https://doi.org/10.18326/rgt.v13i1.49-76

Balasubramanian, K., Jaykumar, V., \& Fukey, L. N. (2014). A Study on "Student Preference towards the Use of Edmodo as a Learning Platform to Create Responsible Learning Environment." Procedia - Social and Behavioral Sciences, 144, 416-422. https://doi.org/10.1016/j.sbspro.2014.07.311

Basak, S. K., Wotto, M., \& Bélanger, P. (2018). E-learning, M-learning and D-learning: Conceptual definition and comparative analysis. E-Learning and Digital Media, 15(4), 191-216. https://doi.org/10.1177/2042753018785180

Blake, R. J. (2007). New trends in using technology in the language curriculum. Annual Review of Applied Linguistics, 271), 76-97. https://doi.org/10.1017/S0267190508070049

Celik, S. (2013). Internet-assisted technologies for English language teaching in Turkish universities. Computer Assisted Language Learning, 26(5), 468-483. https://doi.org/10.1080/09588221.2012.692385

Durak, G. (2017). Using social learning networks (SLNs) in higher education: Edmodo through the lenses of academics. International Review of Research in Open and Distance Learning, 18(1), 84-109. https://doi.org/10.19173/irrodl.v18i1.2623

Ferdiansyah, S., Supiastutik, S., \& Angin, R. (2020). Thai Students' Experiences of Online Learning at Indonesian Universities in the Time of the COVID-19 Pandemic. Journal of International Students, 10(S3), 58-74. https://doi.org/10.32674/jis.v10iS3.3199

French, A. M., Guo, C. J., \& Shim, J. P. (2014). Current status, issues, and future of bring your own device (BYOD). Communications of the Association for Information Systems, 35, 191-197. https://doi.org/10.17705/1cais.03510

Hamidi, S. R., Salleh, K., Shuhidan, S. M., \& Lokman, A. M. (2020). The Adoption of Learning Management System: A Case Study of Schoology and Edmodo. In H. Shoji, S. Koyama, T. Kato, K. Muramatsu, T. Yamanaka, P. Lévy, K. Chen, \& A. M. Lokman (Eds.), Proceedings of the 8th International Conference on Kansei Engineering and Emotion Research (Issue September, pp. 105-114). Springer, Singapore. https://doi.org/10.1007/978-981-15-7801- 
4_11

Hastowahadi, H., Setyaningrum, R. W., \& Pangesti, F. (2020). Pembelajaran Jarak Jauh Darurat COVID-19: Cerita Mahasiswa Internasional di Kelas Bahasa Indonesia untuk Penutur Asing (BIPA). Journal of International Students, 10(S3), 180-197. https://www.ojed.org/index.php/jis/article/view/3206

Kerimbayev, N., Kultan, J., Abdykarimova, S., \& Akramova, A. (2017). LMS Moodle: Distance international education in cooperation of higher education institutions of different countries. Education and Information Technologies, 22(5), 2125-2139. https://doi.org/10.1007/s10639016-9534-5

Lamb, M., \& Arisandy, F. E. (2020). The impact of online use of English on motivation to learn. Computer Assisted Language Learning, 33(1-2), 85-108. https://doi.org/10.1080/09588221.2018.1545670

Martin, F., Sun, T., \& Westine, C. D. (2020). A systematic review of research on online teaching and learning from 2009 to 2018. Computers and Education, 159(April), 104009. https://doi.org/10.1016/j.compedu.2020.104009

Monalisa, M., \& Ardi, H. (2013). Using Edmodo educational social network in teaching English for high school students. Journal of English Language Teaching, 2(1), 220-225. https://doi.org/10.24036/jelt.v2i1.2609

Nurakun Kyzy, Z., Ismailova, R., \& Dündar, H. (2018). Learning management system implementation: a case study in the Kyrgyz Republic. Interactive Learning Environments, 26(8), 1010-1022. https://doi.org/10.1080/10494820.2018.1427115

Osman, M. E. T. (2020). Global impact of COVID-19 on education systems: the emergency remote teaching at Sultan Qaboos University. Journal of Education for Teaching, 46(4), 463-471. https://doi.org/10.1080/02607476.2020.1802583

Pei, L., \& Wu, H. (2019). Does online learning work better than offline learning in undergraduate medical education? A systematic review and meta-analysis. Medical Education Online, 24(1). https://doi.org/10.1080/10872981.2019.1666538

Raaper, R., \& Brown, C. (2020). The Covid-19 pandemic and the dissolution of the university campus: implications for student support practice. Journal of Professional Capital and Community, 5(3-4), 343-349. https://doi.org/10.1108/JPCC-06-2020-0032

Schlenz, M. A., Schmidt, A., Wöstmann, B., Krämer, N., \& Schulz-Weidner, N. (2020). Students' and lecturers' perspective on the implementation of online learning in dental education due to SARS-CoV-2 (COVID-19): a cross-sectional study. BMC Medical Education, 20(1), 354. https://doi.org/10.1186/s12909-020-02266-3

Siahaan, E. B. (2020). Students' Perception of Edmodo use as a Learning Tool. JET (Journal of English Teaching), 6(February), 12-23. https://doi.org/10.33541/jet.v6i1.1061

Sohrabi, C., Alsafi, Z., O'Neill, N., Khan, M., Kerwan, A., Al-Jabir, A., Iosifidis, C., \& Agha, R. (2020). World Health Organization declares global emergency: A review of the 2019 novel coronavirus (COVID-19). International Journal of Surgery, 76(February), 71-76. https://doi.org/10.1016/j.ijsu.2020.02.034

Tarmini, W., Safi'i, I., Witdianti, Y., \& Larassaty, S. (2020). Peningkatan kompetensi profesional guru melalui webinar evaluasi hasil belajar bagi guru-guru MTs Al-Ma'arif 1 Aimas. Transformasi: Jurnal Pengabdian Masyarakat, 16(1), 53-62. https://doi.org/10.20414/transformasi.v16i1.2049

Tsai, P. W., Tsai, P. S., Ku, P., Istanda, V., \& Gabe, T. (2017). Application of e-learning in teaching of english as a second language. Advances in Intelligent Systems and Computing, 535, 163170. https://doi.org/10.1007/978-3-319-48499-0_20

Unal, E., \& Uzun, A. M. (2020). Understanding university students' behavioral intention to use Edmodo through the lens of an extended technology acceptance model. British Journal of Educational Technology, O(0), 1-19. https://doi.org/10.1111/bjet.13046

Widodo, H. P. (2014). Methodological considerations in interview data transcription. International Journal of Innovation in English Language, 3(1), 101-107. 